\title{
A NEW PERIODICAL ON THE UNITED STATES IMMIGRATION LAW
}

Responding to a growing demand for clearer information about an obscure and complex area of law in the United States, the International Common Law Exchange Society (P.O. Box 51, Palo Alto, California 94302, U.S.A.) began to publish in 1979 a monthly periodical entitled the Transnational Immigration Law Reporter. Geared towards the practical solution of real problems rather than academic research, the Transnational Immigration Law Reporter contains short articles on critical issues of immigration law as well as informative notes on the latest legislative, judicial and administrative developments in that area of law. It is now in its second year of publication, and the publishers advise that its contents are about to be listed in the Index to Legal Periodicals and other relevant index services. The annual subscription is US $\$ 125$.

As this is one of very few regular periodical publications on the United States immigration law (for a reason hard to understand the big looseleaf publishers have ignored this area of law so far), the Transnational Immigration Law Reporter may be worth a trial subscription by firms and institutions engaged in immigration law work.

\section{A NEW ENCYCLOPEDIA OF CANADIAN LAW}

Butterworths announces the publication in 1982 of a new encyclopedia of the laws of Common-Law Canada. The work is expected to consist of thirty-two volumes. Modeled on Halsbury's Laws of England it will nevertheless differ from Halsbury in that it will be published by broad topic rather than by title. For example, the titles "Affiliation and Legitimation," "Divorce," "Husband and Wife," and "Infants, Children and Young Persons" appear in Halsbury in separate volumes published at intervals within the alphabetical sequence. In Laws of Canada these titles will all be grouped under the topic "Family" and will be published in one volume. This will give attorneys access to functionally related areas of law and will also free the work from any artificial adherence to an alphabetical title sequence.

The first volume of the Laws of Canada is planned to appear in 1982. The completion of the whole set is expected to take eight years. The price is anticipated to range Can $\$ 50$-Can $\$ 60$ per volume.

\section{AUSTRALIAN LEGAL DICTIONARY}

Collectors of legal dictionaries may be interested in the publication of S.E. Marantelli's Australian Law Dictionary. It is a convenient guide to Austrialian legal practice, including the use of Latin expressions in 
Australia, historical terms, local legal jargon, and words commonly used by the legal profession in that country. There are ample references to Australian legislation and, less frequently, to the case law of that country. Published in 1980 by Hargreen Publishing Co., Melbourne, the 248-page long Australian Legal Dictionary is priced at Aus $\$ 5.85$. (Australian Law Librarians' Group Newsletter, No. 38, June 1980. For further information write to Rob Brian, Law Library, University of New South Wales, Kensington, NSW, Australia.)

\section{JAPANESE FOREIGN EXCHANGE AND FOREIGN TRADE CONTROL LAW : ENGLISH TRANSLATION}

Business activities of foreign corporations and other trading entities were made considerably easier in Japan by the recently introduced Law Partially Amending the Foreign Exchange and Foreign Trade Control Law (Law No. 65 of 1979). Introduced as a direct result of criticisms made by the representatives of Japan's main trading partners at the Tokyo Rounds about the difficulties of importing foreign goods into Japan, the amendments purport to simplify many procedural and substantive requirements previously imposed on foreign business organizations operating in Japan.

An English translation of the entire Foreign Exchange and Foreign Trade Control Law, as amended in 1979, is now available in JASLS Reports: Newsletter of the Japanese American Society for Legal Studies, American Branch, 1980 issue No. 1. The 46-page long translation into excellent English legal drafting language was made by Andrew B. Anderson, III, who is an associate with the firm of Mudge, Rose, Guthrie and Alexander of New York.

\section{NEW PERUVIAN BOOK ON INHERITANCE LAW}

The Press of the Universidad Católica del Perú has published a book on inheritance law- "La Sucesión Hereditaria en la Jurisprudencia Peruana" (767 pp., 1980, US \$35) consisting of leading cases selected and commented upon by Dr. José León Barandiarán.

Dr. León is a very important author of legal treaties on Private Law, professor of Universidad Católica, Universidad de San Marcos and Universidad San Luis Gonzaga de Ica, and former Minister of Justice.

The book was presented to the public by Dr. Fernando de Trazegnies, President of the University Press, and Dr. Hector Cornejo Chávez, Professor of Inheritance Law of that University. The meeting was held on May 27th and had the assistance of the most relevant personalities in the legal area, such as Dr. José Luis Bustamante y Rivero, Judge of the International Court of The Hague and former President of the Republic, mem- 